\title{
Penal Mediation Policy According to Indonesian Criminal Laws to the Protection of Criminal Victims Domestic Violence
}

\author{
Roberts Kennedy, S.I.K, S.H., M.Hum \\ Lecturer at the Faculty of Law, Batam University, Indonesia
}

http://dx.doi.org/10.18415/ijmmu.v6i3.1038

\begin{abstract}
Domestic violence is a form of violation of human rights and crimes against humanity, it is also an act of discrimination. This is also regulated in the 1945 Constitution Article $28 \mathrm{G}$ paragraph (1) and Article $28 \mathrm{H}$ paragraph (2) of the 1945 Constitution. In the principle of equality the most fundamental thing of human rights is to place people born free and have equality in human rights, while the principle of violation of discrimination is an important part of the principle of equality. This study examines the problem. There are several obstacles that make it difficult to eradicate domestic violence in Indonesia including the rigidity of law enforcement in enforcing regulations and most are still guided by the Criminal Code even though there are regulations governing domestic violence. And there are some weaknesses in the Criminal Code in handling domestic violence.
\end{abstract}

Keywords: Penal Mediation Policy; Indonesian Criminal Laws; The Protection of Criminal Victims; Domestic Violence; Law

\section{A. Background}

Consideration of Law No. 23 of 2004 concerning the Elimination of Domestic Violence (hereinafter referred to as the PKDRT Law) points a, b and c explain that every citizen has the right to get a sense of security from all forms of violence ${ }^{1}$ especially against women ${ }^{2}$, in reality many cases of

\footnotetext{
${ }^{1}$ Ratna Batara Munti in Novianty Djafri, Journal of INNOVATION, Volume 5, Number 4, December 2008 ISSN 1693-9034, p. 246 explains that violence against women in the household can occur in various forms as summarized below, namely: 1) Direct physical violence in the form of beatings, burning to vaginal destruction (sexual violence) and indirect physical violence which usually involves hitting the table, slamming doors, breaking plates, cups, places of flowers and others, and being abusive.2) Psychological violence, in the form of harsh words, dirty, and which connotes disparaging and insulting, silence, terrorizing both directly or using certain media, cheating, and leaving leave without clarity for a long time and without responsibility.3) Economic violence, in the form of not providing a living during marriage or limiting the living arbitrarily, allowing or even forcing a wife to work hard, also does not provide a living after a divorce even though the court decides. 4 . The combination of various violence as mentioned above both physical, psychological, and economic. See also, A.Nunuk.P.Murniati, Op Cit. p. 223, and Kristi Purwandari in the work group "convention Watch" Center for Women's and Gender studies at the University of Indonesia editor:
} 
domestic violence occur, while the legal system in Indonesia has not guaranteed protection for victims of domestic violence ${ }^{3}$.

Before the adoption of the PKDRT Law in many cases of violence that occurred in general, the perpetrators were exposed to legal threats under Article 351 of the Criminal Code (persecution), Article 352 of the Criminal Code (mild persecution), Article 353 of the Criminal Code (planned persecution), Article 354 of the Criminal Code (severe persecution), Article 355 of the Criminal Code (planned severe persecution), if the act is committed to his mother, father according to the law, his wife or child, then the threat of punishment is increased by one third. The above provisions although it does not specifically regulate domestic violence, but at least it can be used to complain the perpetrators to the police and even the Criminal Code gives the threat of a heavier sentence if the torture was carried out against a wife or husband who clearly according to him because the weighting of this sentence is also intended to the husband or wife who committed the persecution, then at least Article 356 contains the principle of gender justice ${ }^{4}$.

The formation of the PKDRT Law which was passed on 22 September 2004 is inseparable from the role of the government in it because the law is the legal basis that forms the basis of all policies to be made by the government ${ }^{5}$, and is expected to be made as an adequate legal instrument, in which among others, it regulates the prevention, protection of victims ${ }^{6}$, and repression of perpetrators of domestic violence, while maintaining integrity for the sake of family harmony. But in fact in general cases of domestic violence in Indonesia is still high, and even tends to increase.

Domestic violence is a major cause of divorce. Within the scope of the Religious Court, divorce must be completed first with mediation in accordance with Marriage Law No.1 of 1974. While in the District Court there is no legal basis governing mediation as an alternative settlement. Within the criminal sphere, penal mediation is better known as a method of handling domestic violence cases.

Based on the PKDRT Law Article 1 point 1 states that Domestic Violence is any act against a person, especially women, which results in physical, sexual, psychological, and / or misery or neglect of the household including threats to commit acts, coercio, or unlawfully deprivation of liberty within the household. Likewise Article 2 paragraph 1 states that the scope of households in this Law includes:

1. Husband, wife and children (including adopted children and stepchildren);

2. People who have a family relationship with the person as referred to in letter a because of blood, marriage, nursing, care and guardianship, who live in the household (in-laws, in-laws, in-laws, in-laws and in-laws);

Achie Sudiarti Luhulima Pemahaman Bentuk-bentuk Tindak Kekerasan Terhadap Perempuan dan Alternatif Pemecahannya, Alumni, Jakarta, 2000, p. ix, as well as Article 5 of Law Number 23 of 2004 concerning the Elimination of Domestic Violence.

${ }^{2}$ Concerning Law Number 23 of 2004 concerning the Elimination of Domestic Violence a, a) every citizen has the right to feel safe and free from all forms of violence in accordance with the philosophy of the Pancasila and the 1945 Constitution of the Republic of Indonesia; b) all forms of violence, especially domestic violence, constitute violations c) victims of domestic violence, most of whom are women, must receive protection from the state and / or society to avoid and be free from violence, torture, or degrading treatment and human dignity.

${ }^{3}$ Consideration of Law Number 23 of 2004 concerning the Elimination of Domestic Violence letter d.

${ }^{4}$ Nursyahbani Katjasungkana, Seminar Aspek Hukum Kekerasan Terhadap Perempuan, BPHN, Jakarta, 15-16 December 1994.

${ }^{5}$ Yuliandri, 2010, Asas-asas Pembentukan Peraturan Perundang-undangan Yang Baik (gagasan Pembentukan Undang-Undang Berkelanjutan), p.1.

${ }^{6}$ Article 1 number 4 of Law Number 23 of 2004 concerning the Elimination of Domestic Violence states that protection is "all efforts aimed at providing security to victims carried out by the family, advocates, social institutions, police, prosecutors, courts, or parties others, both temporarily and based on the determination of the judge. 
3. People who work help the household and stay in the household (Domestic Workers) ${ }^{7}$.

The purpose of the PKDRT Law is, of course, that even if criminal punishment occurs, the crime imposed will tend to be mild so that the final point is expected to be the marriage of the perpetrator and the victim will not break ${ }^{8}$. However, many cases of domestic violence are subject to imprisonment rather than fines. This prison sentence imposed by the judge should be questioned whether imprisonment can have a deterrent effect on the convicted given that many cases of domestic violence are committed by husbands against wives by reasoning to educate wives to be obedient and obedient to their husbands, especially with the adoption of a patriarchal system in the community. giving men a dominant place to be the head of the household and at the same time policy makers in the household, in fact many cases of perpetrators who are then reported or complained of committing domestic violence have initially been victims of other types of domestic violence committed by actual victims is the initial offender in the process of giving birth to a series of domestic violence within the scope of his household.

In 2017 the number of reported cases increased by 74\% from 2016. The number of 2017 KTP cases amounted to 348,446 , this number jumped considerably compared to the previous year of 259,150 .. Based on the collected data the most prominent types of violence against women are the same as the previous year was domestic violence / RP (personal domain) which reached 71\% $(9,609)$. The personal domain is the most widely reported and not a few of them experience sexual violence. The second position is the KtP in the community / public domain with a percentage of $26 \%(3,528)$ and the last is the $\mathrm{KtP}$ in the state domain with a percentage of $1.8 \%$ (217). In the realm of domestic violence / RP the most prominent violence was physical violence 3,982 cases $(41 \%)$, ranked first followed by sexual violence cases $2,979(31 \%)$, psychological $1,404(15 \%)$ and economic 1,244 cases $(13 \%)^{9}$.

The data above does not show the actual number of domestic violence, it is believed there are still many cases of domestic violence that are not reported ${ }^{10}$ or raised into the realm of criminal law (dark number). The increase in the number of cases of violence against women in the household among others is motivated by a variety of factors, internal factors ${ }^{11}$, external factors ${ }^{12}$, cultural factors ${ }^{13}$, ideology and to

\footnotetext{
${ }^{7}$ Rochmad Wahab, Kekerasan Dalam Rumah Tangga (Perspektif Psikologis dan edukatif) www.http://staff.uny.ac.id/dosen/profdr-rochmat-wahab-mpd-ma (August 21, 2013)

${ }^{8}$ Guse Prayudi, 2008, Berbagai Aspek Tindak Pidana Kekerasan Dalam Rumah Tangga, Yogyakarta: Merkid Press, p. 120

${ }^{9}$ Komnas Perempuan, Tergerusnya Ruang Aman Perempuan Dalam Pusaran Politik Populisme, Catatan Kekerasan Terhadap Perempuan Tahun 2017, Catatan Tahunan Tentang Kekerasan Terhadap Perempuan, 2018.

${ }^{10}$ In Luhulima, USA, 2000, Pemahaman Bentuk-Bentuk Kekerasan terhadap Perempuan dan Alternatif Pemecahannya, Jakarta: PT. Alumni: Harkrisnowo stated the causes of non reporting crime were: 1) The victim was ashamed because this incident had defiled herself both physically, psychologically, socially; 2) The victim is obliged to protect the good name of his family, especially the perpetrators are family members; 3 ) The victim feels that the criminal justice process may not necessarily make the conviction of the maker; 4) The victim was worried that the processing of this case would bring even higher pollution to him, for example publication in the mass media; 5) The victim is afraid that there is retaliation from the perpetrator; 6) The location of the police station far from the victim's residence made him reluctant to report; 7) Victim's belief that even if he reports he will not get special protection from law enforcement; 8) The victim's ignorance that what was done against her is a form of violence.

${ }^{11}$ Moerti Hadiati Soeroso 2010, Kekerasan Dalam Rumah Tangga Dalam Perspektif Yuridis-Viktimologis, Jakarta: Sinar Grafika, p. 136-137, states: obstacles that come from victims (internal) can occur because: a) victims do not know that acts of violence committed by their husbands constitutes a criminal act or an action which can be punished. Therefore, victims do not report acts of violence they experienced; b) the victim allows acts of violence against him to be protracted. This could be because the victim believes that the husband's actions will change; c) the victim believes what she experienced was her destiny or fate as a wife. This could be because the victim believes that the husband's actions will change; d) victims have economic dependence on perpetrators of violence; e) the victim maintains her social status, so that if the violence that occurs in the household is known to others, it will worsen the social status of her family in the community; f) the victim is afraid of threats from her husband; g) the victim is worried that the family will blame her for not being able to solve her own household problems; h) victims are late in reporting acts of violence experienced, so physical evidence is lost.

${ }^{12}$ Moerti Hadiati Soeroso, 2010 p.137-138, stated: external barriers 1) Barriers can be imposed by victims' families, because domestic violence is a family disgrace that must be covered so that it is not known by the community. Another reason is because acts of violence that occur in the household are domestic or family internal affairs.2) Other obstacles come from the community. There are still opinions that assume domestic violence is a family affair not a crime that can be resolved through legal means. Such opinion still colors various circles in the community, so that it will be an obstacle for law enforcement in the field of
} 
the community awareness that is still low on the problem of violence experienced, even violence experienced by women in the household is still considered a normal problem ${ }^{14}$. This is often caused because domestic violence is often continuous (cyclical violence), for perpetrators of domestic violence themselves consider this to be a natural thing.

\section{B. Research Problems}

Based on the background explanation of the problem above, the problems that are the subject of the study in this study are:

1. What is the arrangement for the protection of women victims of domestic violence?

2. How is the concept of media sanction protection for women victims of domestic violence in criminal law policies?

3. What is the concept of regulating the protection of women victims of domestic violence in the perspective of future criminal law?

\section{Research Methods}

Method is the study of research methods and the science of tools for research ${ }^{15}$. The research method is the science of the levels that must be passed in a research process, or the science that discusses scientific methods in finding, developing, and testing the truth of a knowledge ${ }^{16}$. Peter Mahmud Marzuki stated that legal research is a process of finding legal rules, legal principles, and legal doctrines in order to address the legal issues at hand ${ }^{17}$.

domestic violence, 3) Barriers from the State: a) This barrier is in the form of a provision that the cost of visum et repertum must be incurred by the victim. For victims who are unable, this is an obstacle in seeking justice. b) In addition, the inclusion of physical, psychological and sexual violence perpetrated by the husband against the wife in the offense of complaint, severely limits the space for the wife. Even though the law does not mention absolute offense or relative offense, it still puts the wife in a subordinate position. This is stated in Articles 51, 52 and 53 of Law Number 23 of 2004. Though initially it was determined that domestic violence is an offense, an act that can be legally processed.

${ }^{13}$ Bashim Kamla 1996, Suing Patriaki, Menggugat Patriaki, Pengantar Tentang Persoalan Terhadap Kaum Perempuan, Nursyahbani Translation. Katjasungkana, What is Patriartichy, Yogyakarta: Benteng Kalyamamitra, p. 1: "The attachment of the patriarchal system is an ideology which states that men are higher than women and that women must be controlled by men and that women belong to men".

${ }^{14}$ In Silfia Hanani, Mengatasi Kekerasan Dalam Rumah Tangga Melalui Institusi Adat Minangkabau (Suatu Upaya Dalam Mewujudkan Kesejahteraan Berbasis Perspektif Lokalitas dan Religius),Conference Proceeding, Annual International Conference on Islamic studies (AICIS XII), p.. 576 The number of cases of domestic violence that have not been reported to the parties responsible, one of which is caused by the community's awareness that is still low about this. Domestic violence cases are still considered as domestic cases that are not able to be published. This has become one of the causes of the non-touching settlement of domestic violence cases in Indonesia.

${ }^{15}$ Noeng Muhadjir, Metodologi Penelitian Kualitataif, Rake Sarasin, Yogyakarta, 1993, p.15

${ }^{16}$ Rianto Adi, Metodologi Penelitian Sosial dan Hukum, Granit, Jakarta, 2004, p. 1.

${ }^{17}$ Peter Mahmud Marzuki., Penelitian Hukum, Kencana, Jakarta, Cet. VI, 2010, p. 35 
The data in this study were obtained or collected primarily by using secondary data and supported by primary data. Secondary data is data obtained from library research and documentation, which are the results of research and processing of others, which are already available in the form of books or documentation that are usually provided in libraries, or private property ${ }^{18}$. Analysis is interpreted as the process of decomposition of the consistency of certain symptoms ${ }^{19}$. The analysis referred to here is an analysis of primary legal materials, secondary legal materials and non-legal materials. Considering this research is categorized as normative legal research, the analysis of legal material is carried out with qualitative normative analysis ${ }^{20}$. Therefore the data analysis that is carried out is an analysis of the content or content analysis ${ }^{21}$.

\section{Discussion}

\section{Overview of Domestic Violence in Indonesia}

Data on violence against women from year to year tends to increase. Violence in the personal realm still occupies the highest position. Acts of violence against women are generally like a pyramid that is small at the peak but large at the bottom, because to get exact figures is very difficult. Especially if the violence occurs in the household, because the problem is still considered taboo and is still considered a family problem that is resolved by family. This shows that there are still many female victims of domestic violence who keep their mouths shut and keep the issue tight.

The number of cases of violence against women is like an iceberg phenomenon, this is because to know the amount of violence against women is only based on data reports from the public. The facts in the field are expected to be more alarming. Many incidents of violence against women are not reported because they are considered a family disgrace. Women also tend to choose silence and harbor their own problems of violence, for fear that if he talks and asks for support from others he will be blamed.

Domestic violence according to the PKDRT Law is any act against a person, especially women, which results in physical, sexual, psychological, and / or neglect or suffering of the household, including threats to coercive acts, or illegal deprivation of liberty in law household scope. Domestic violence is a deeply rooted problem that occurs in all countries of the world. Domestic violence is a greater danger for women than robbery and theft. Statistics in America show that every 9 minutes women become victims of physical violence, and $25 \%$ of women are killed by their male partners ${ }^{22}$.

\footnotetext{
${ }^{18}$ Hilman Hadikusuma.,1995, Metode Pembuatan Kertas Kerja Atau Skripsi Ilmu Hukum, Bandung:Mandar Maju, p. 65

${ }^{19}$ Soerjono Soekanto dan Sri Mamudji, 2010, Op.Cit .p. 63.

${ }^{20}$ Soejono dan Abdurrahman, Metode Penelitian Suatu Pemikiran dan Penerapan, Rineka Cipta, Jakarta, 2005, p. 56

${ }^{21}$ Lexy Y. Maleong, 1999, Metode Penelitian Kualitatif, Jakarta: Remadja Karya, Jakarta ,p. 9.

${ }^{22}$ Sonda M.2010, Dampak Kekerasan Dalam Rumah Tangga Terhadap Gangguan Reproduksi Wanita di RS Bhayangkara. Makasar: Kebidanan Poltekes. p.2.
} 
Table Violence against Women (KTP) in Indonesia

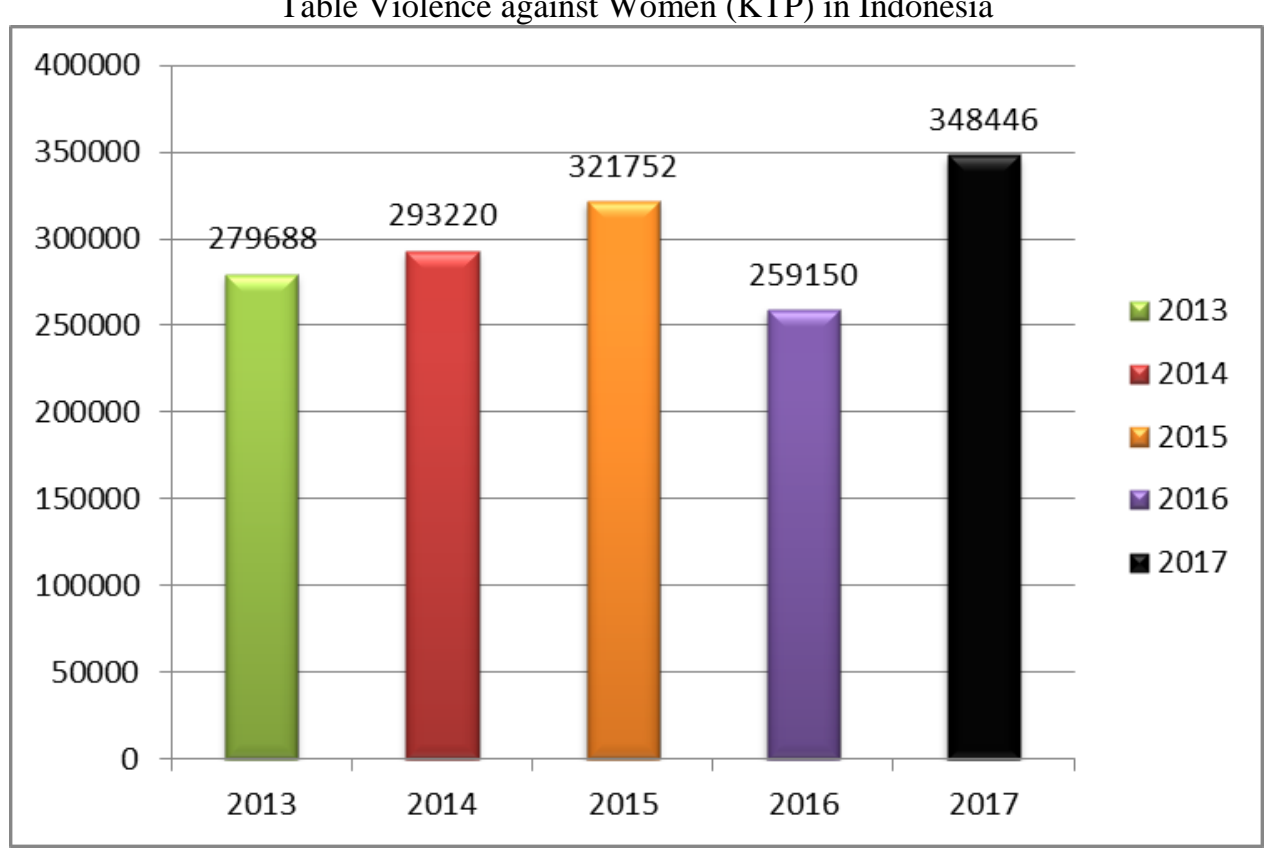

Source: CATAHU Komnas Perempuan Tahun 2013-2017

Annual Note (CATAHU) The National Commission on Violence Against Women (Komnas Perempuan) records cases of violence against women received by various community institutions and government institutions spread across almost all provinces in Indonesia, as well as direct complaints received by Komnas Perempuan through the Unit Referral Complaints (UPR) and through the Komnas Perempuan official e-mail, in the past one year. In 2017 Komnas Perempuan sent 751 forms to Komnas Perempuan partner institutions throughout Indonesia with a response rate of return reaching $32 \%$, which is 237 forms. In 2017 the number of reported cases increased by 74\% from 2016. The number of 2017 KTP cases amounted to 348,446 , this number jumped considerably compared to the previous year of 259,150. Most of the data comes from cases or cases handled by PN / PA. This data was collected from 3 sources namely; (1) From the PN / Religious Courts totaling 335,062 cases, (2) from Komnas Perempuan partner service institutions totaling 13,384 cases, (3) from the Service and Referral Unit (UPR), one unit deliberately formed by Komnas Perempuan to receive complaints from victims come directly to the National Commission on Violence against Women and (4) from the monitoring division that manages complaints that come in via mail and electronic mail ${ }^{23}$.

Based on the data collected, the most prominent type of violence against women as in the previous year was domestic violence / RP (personal domain), which reached $71 \%(9,609)$. The personal domain is the most widely reported and not a few of them experience sexual violence. The second position is the KTP in the community / public domain with a percentage of $26 \%(3,528)$ and the last is the KTP in the state domain with a percentage of $1.8 \%$ (217). In the realm of domestic violence / RP the most prominent violence was physical violence 3,982 cases $(41 \%)$, ranked first followed by sexual violence cases $2,979(31 \%)$, psychological 1,404 (15\%) and economic 1,244 cases (13\%). In the public sphere and community violence against women recorded 3,528 cases. $76 \%$ of violence against women in the Public or Community Domain is Sexual Violence namely Sexual Abuse (911), Sexual Harassment (704) and Rape $(699)^{24}$.

\footnotetext{
${ }^{23}$ Komnas Perempuan, 2018, Catatan Tahunan Tentang Kekerasan Terhadap Perempuan tahun 2017, Jakarta: Komnas Perempuan.

${ }^{24}$ Ibid.
} 
Meanwhile there were 343 cases of intercourse. In the domain of (which is the responsibility of) the State, cases of evictions that are reported and or monitored that occur in residents of Batu Ampar (Bali) and Cilincing (Jakarta) and cases of threat of eviction in Taman Sari (West Java) and residents of Baraya Raya (South Sulawesi) . For violence in the realm of household / personal relations, violence against wives (KTI) ranks first in 5,167 cases (54\%), followed by dating violence in 1,873 cases (19\%), violence against girls in 2,227 cases (23\%) and the remainder in violence ex-husband, ex-boyfriend violence, as well as violence against domestic workers. The high rate of violence against girls in 2018 CATAHU shows that being a girl in the house is no longer a safe thing. Among them experienced sexual violence. Even the most worrisome aspect is the incest case of 1,210 where the offender is a biological father by 425 . The attention and courage to report cases experienced by girls to service institutions shows that the woman's step forward has tended to close and foster the impunity of perpetrators of family members ${ }^{25}$.

\section{Restorative Justice Approach as an effort to bring about justice and balance for victims of domestic violence}

As a logical consequence of the thought that the state through its organs or instruments of power has the authority to determine what actions are prohibited or required to be carried out (criminal law in an objective sense (ius poenale) as well as the authority to impose penalties in accordance with what has been the law is determined for every person who commits an act that is prohibited or does not commit an act which is actually required to be carried out (criminal law in the subjective sense (ius puniendi) ${ }^{26}$, in the criminal justice system, the criminal act is then understood as an attack on the state ${ }^{27}$, crime is seen as a conflict between the perpetrators of crime with the state ${ }^{28}$.

Meanwhile, the criminal justice system can be described briefly as a system that aims to tackle crime, one of the people's efforts to control the occurrence of crime so that it is within acceptable tolerance limits ${ }^{29}$. Besides aiming to prevent people from becoming victims of crime and trying so that those who have committed crimes do not repeat their actions, one of the objectives of the criminal justice system is to resolve crimes that occur so that people are satisfied that justice has been upheld and the guilty criminal is convicted. Therefore, justice is then understood as imposing a sentence on the perpetrators in the event that the indictment or accusation is legally proven ${ }^{30}$.

Restorative justice or often translated as restorative justice is a model approach in the effort to resolve criminal cases in response to the criminal justice system that is considered unable to accommodate the aspirations of perpetrators and victims ${ }^{31}$. What makes this restorative justice approach different when compared to the criminal justice system is that it puts forward the concept of mediation and reconciliation as a mechanism for resolving disputes or conflicts in the event of a crime, something that has not been recognized in the criminal justice system $^{32}$.

\footnotetext{
25 Ibid.

${ }^{26}$ Jan Remmelink, Hukum Pidana; Komentar atas Pasal-Pasal Terpenting dari Kitab Undang-Undang Hukum Pidana Belanda dan Padanannya dalam Kitab Undang-Undang Hukum Pidana Indonesia 1-3, Gramedia Pustaka Utama, Jakarta, 2003 , p. 54.

${ }^{27}$ Eva Achjani Zulfa, Reparasi dan Kompensasi Korban Dalam Restorative Justice, Lembaga Perlindungan Saksi dan Korban dan Departemen Kriminologi FISIP UI, Jakarta, 2011, p. 12.

${ }^{28}$ Ibid.

29 Mardjono Reksodiputro, Mengembangkan Pendekatan Terpadu Dalam Sistem Peradilan Pidana, Pra Seminar Hukum Nasional V, Jakarta, January 21, 1986.

${ }^{30}$ Eva Achjani Zulfa, Konsep Dasar Restorative Justice, Training in Criminal Law and Criminology, Principles of Criminal Law and Criminology and Their Development Today, Gajah Mada University, Yogyakarta, February 23-27, 2014

${ }^{31}$ Ibid.

${ }^{32}$ Ibid.
} 
This approach is based on efforts to balance the focus between victims, perpetrators and communities affected by criminal acts with the main goal of creating peace in the community by restoring the relationship between the parties (perpetrators and victims) and repairing various damages as a result of a crime considered as a dispute or conflict in social relations.

If compared, there are indeed different perspectives in understanding crime and justice in the criminal justice system and the restorative justice approach. The difference between the two can be described as follows:

Table 2: Differences in Perspective Ways to Understand Criminal Acts and Justice in the Criminal Justice System and the Restorative Justice Approach

\begin{tabular}{|l|l|l|}
\hline Indicator & Criminal Justice System & Restorative Justice Approach \\
\hline offenses & $\begin{array}{l}\text { Criminal action is understood as } \\
\text { an attack on the State, a logical } \\
\text { consequence of understanding } \\
\text { the concepts of ius poenale and } \\
\text { ius puniendi. }\end{array}$ & $\begin{array}{l}\text { Crime is understood as an attack on } \\
\text { individuals and social relations, a } \\
\text { consequence of the thought that Crime } \\
\text { in principle causes damage to } \\
\text { relationships between individuals in } \\
\text { society. }\end{array}$ \\
\hline Understanding of justice & $\begin{array}{l}\text { Justice is considered to be } \\
\text { realized by referring to the } \\
\text { number of cases being processed } \\
\text { and the criminal sentences } \\
\text { against the perpetrators. }\end{array}$ & $\begin{array}{l}\text { Justice is considered to be realized in } \\
\text { terms of: } \\
\text { - Finding the best solution for the } \\
\text { perpetrators, victims and the community } \\
\text { to resolve disputes or conflicts that } \\
\text { occur (win win solution) so that social } \\
\text { relations that were damaged can be } \\
\text { restored. } \\
\text { - The agreement of the parties can really } \\
\text { be implemented. }\end{array}$ \\
\hline
\end{tabular}

Source (processed): Burt Galaway and Joe Hudson, Criminal Justice, Restitution and Reconciliation (Criminal Justice Press, New York, 1990).

Victims of domestic violence can include husbands, wives, children or even people who live within the scope of the household. Victims of domestic violence are entitled to obtain their rights as stipulated in the PKDRT Law. Substantially, of course, with the existence of articles containing the rights of victims, it is expected that victims of domestic violence will receive protection from the state and / or society so that it does not result in prolonged traumatic impacts. In accordance with the consideration of the PKDRT Law, victims of domestic violence, most of whom women must receive protection from the State and / or society to avoid and be free from violence or threats of violence, torture, or degrading treatment and human dignity.

But in practice, the settlement of criminal cases in court, often the law places too much emphasis on the rights of the suspect / defendant, while the rights of the victim are ignored. Many crime victims are found to lack adequate legal protection, both immaterial and material protection. Crime victims are placed as evidence that provides information that is only as a witness so that the possibility for victims to gain freedom in fighting for their rights is small ${ }^{33}$. The victim is not given authority and is not actively involved in the investigation and trial process so that he loses the opportunity to fight for his rights and restore his condition due to a crime ${ }^{34}$. Therefore, in this context, several parties consider that the handling of domestic violence cases has not been maximized. This

\footnotetext{
${ }^{33}$ Dikdik M. Arief \& Elisatris Gultom, Urgensi Perlindungan Korban Kejahatan Antara Norma dan Realita, PT. Raja Grafindo Persada, Jakarta, 2007, p.25-26.

${ }^{34}$ Chaerudin dan Syarif Fadillah, Korban Kejahatan dalam Perspektif Viktimologi dan Hukum Pidana Islam, Grhadhika Press, Jakarta, 2003. p.49.
} 
was as revealed by Hani Barizatul Baroroh ${ }^{35}$, due to two things, namely: First, weakness in the PKDRT Law ${ }^{36}$. Second, weaknesses in the Criminal Justice System in Domestic Violence Cases ${ }^{37}$.

\section{Maximizing Customary institutions in preventing and repressive domestic violence cases}

Social facts that have developed so far, domestic violence committed especially against women by their partners and close family members, sometimes also becomes a problem that has never been raised to the surface. Although awareness of the experience of violence against women continues at any time, the phenomenon of domestic violence against women is identified with the nature of the problem of private space. From that perspective, violence as seen as a personal responsibility and women is defined as a person who is responsible either to improve the situation that is actually dictated by social norms or develop methods that can be accepted from unseen suffering ${ }^{38}$.

From the social aspect, violence in the household, in practice is difficult to uncover due to several reasons. First, violence in the household occurs within the scope of household life which is understood as a matter of privacy nature, where other people may not interfere (intervention). Second, in general the victim (wife / child) is a party that is structurally weak and has economic dependence, especially with the perpetrator (husband). In this position, victims generally always take a silent attitude or even cover up the acts of violence, because opening a case of domestic violence to the public means opening up the family's disgrace. Third, the lack of knowledge and legal existence of the community regarding their legal rights. Fourth, there is a social stigma that violence committed by husbands is understood by the community as something that might be considered reasonable in the educational framework carried out by parties who do have the authority to do so. In this position, victims are often reluctant to report to law enforcement officials for fear that they will be blamed (blame the victim) $)^{39}$.

\footnotetext{
${ }^{35}$ Hani Barizatul Baroroh, “Mediasi Penal Sebagai Alternatif.....”, p. 188

${ }^{36}$ Weaknesses stemming from the PKDRT Law include: (1) The PKDRT Law does not have its own procedural law, so that law enforcement officials are guided by the Criminal Procedure Code which is rigid and unfriendly to victims of domestic violence; (2) By not having its own procedural law the PKDRT Law does not provide an opportunity for alternative dispute resolution methods other than the court (for example mediation), even though the court is not always appropriate and suitable in handling the uniqueness of the domestic violence case; (3) The inclusion of physical, psychological, sexual violence committed by the husband against his wife in absolute complaint offense. This placement makes the domestic violence reporter only be done by his wife. That certainly greatly limits the space for the wife to place the wife in a subordinate position; (4) The PKDRT Law provides an opportunity for the Criminal Code treatment because there are no rules to repeal the provisions in the same criminal offenses; (5) The threat of the PKDRT Law in the form of alternatives (imprisonment or fines) should be in the form of cumulative (imprisonment and or fines) so that it can have a deterrent effect on domestic violence perpetrators. (6) The PKDRT Law does not regulate threats to perpetrators.

${ }^{37}$ Weaknesses in the settlement of the criminal justice system against domestic violence, according to Fatahillah A. Syukur, are triggered by several factors, including: (1) In the trial process the parties are not given sufficient time and opportunity to participate in delivering a version of justice; (2) Focusing only on legal facts and ignoring emotional factors causes the court not to give victims the opportunity to share their suffering; (3) The long, rigid and complicated procedures of law enforcement agencies ignore victims, make it difficult to achieve satisfactory results, and tend to double the suffering of victims; (4) The high cost of litigation in court; (5) Penalties tend to be motivated by revenge (restitutive justice), and fail to provide a deterrent effect to the perpetrators; (6) The court fails to provide protection to women because often the offender sentenced to a minor sentence will be more abusive to his wife when returning in a married life; (7) Failure to pay attention to the balance of position / strength of the parties in the domestic violence case results in weak protection for victims who are in fact weak; (8) Criminal imprisonment in the form of imprisonment against the perpetrators, the majority of which become the foundation of the family's economy, causes damage to the family and children's future. For more details see, Fatahillah A. Syukur, Mediation on Domestic Violence Cases ..., p. 9-10

38 Suryanti, Kekerasan Dalam Rumah Tangga (Analisis Fakta Sosial Berbasis Konseling Feminis Terhadap Ketimpangan Gender), Jurnal Musawa, Vol. 10 No.1, Juni, 2018.

${ }^{39}$ Abnan Pancasilawati, Kekerasan Dalam Rumah Tangga Perspektif UU NO.23 Tahun 2004 tentang PKDRT dan Hukum Islam, Jurnal Equalita Vol 3 No 2, Juni, 2013.
} 
The problem of domestic violence in Indonesia is experiencing a high increase every year, and women who are often victims. Violence against women has become an important issue and causes anxiety in every country in the world, including developed countries which are said to have great respect for human rights (HAM). The legal culture of society, especially the Malay culture that is still adhered to by our society, has a perception that household affairs are a private area and a disgrace that must not be known or told to others. So this is also one of the inhibiting factors in law enforcement of domestic violence. The application of adat sanctions to deviant behavior including domestic violence in the social structure of indigenous peoples is still cultivated. The existence of customary law is still maintained by the community because settlement of cases through customary law is always prioritized by the principle of kinship, peace, based on the principle of consensus ${ }^{40}$.

Tradition or commonly referred to as customs are a set of values or norms, rules and social beliefs that grow and develop together with the growth and development of rural communities and / or other community units and other norms that are still lived and maintained by the community as manifested in various patterns behavior that is the habits of the local community. Customary law is law that truly lives in the conscience of the conscience of the community and is reflected in their patterns of action in accordance with their customs and socio-cultural patterns that do not conflict with national interests and have sanctions if violations occur. Customary law norms and norms emerge along with the dynamics of human relations. This has resulted in the composition of the association of human life will determine the nature and style of the rule of law, so that in order to understand the customary legal system, it must first be understood the nature and structure of the structure of the community in which customary law grows and develops ${ }^{41}$.

The increase in the number of cases of violence against women in the household among others is motivated by various factors, ranging from cultural, ideological factors and up to the low public awareness of the problem of violence they experienced, even violence experienced by women in the household is still considered a normal problem ${ }^{42}$. No less important, economic problems have also become a significant trigger for cases of violence against women in the household. When viewed from a cultural perspective primarily based on kinship culture, that kinship style does not affect the high or low violence experienced by women in the household. This can be seen from the matrilineal sociocultural in West Sumatra. Where women victims of domestic violence experienced a significant increase. In 2015 there were 132 cases of domestic violence, then in 2004 there were 174 cases, in 2016 there were 287 cases and in 2017 there were 286 cases $^{43}$.

When compared between 2006 and 2005, cases of domestic violence in West Sumatra only dropped by one case. That is, the case of domestic violence is still a problem in areas that adhere to this matrilineal kinship system. In 2007, cases of domestic violence in West Sumatra have increased, more cases are triggered by low public awareness, local ideology and culture as well as economic factors. This is in line with the opinion of Erlangga Masdiana who stated that the increase in domestic violence cases was strongly influenced by the ideology and understanding of the culture of the community. The ideology and culture are still reconstructing by placing the domestic violence problem as a domestic problem, so the domestic violence case is considered an ordinary family problem, so that women allow themselves to be victims of the violence. Finally the case was not

\footnotetext{
${ }^{40}$ Soerojo Wignjondipoero, Pengantar dan Asas-asas Hukum Adat, PT. Toko Gunung Agung, Bandung, 1983, p. 18.

${ }^{41}$ Djaren Saragih, Pengantar Hukum Adat Indonesia Edisi III, Tarsiti, Bandung, 1996, p. 4.

${ }^{42} \mathrm{http} / / / \mathrm{www}$. inststitutionperempuan.org.id. Many cases of domestic violence are not reported to the parties responsible, one of which is caused by low public awareness of this. Domestic violence cases are still considered as domestic cases that are not able to be published. This has become one of the causes of the non-touching settlement of domestic violence cases in Indonesia.

${ }^{43}$ Silfia Hanani, Mengatasi Kekerasan Dalam Rumah Tangga Melalui Institusi Adat Minangkabau (Suatu Upaya Dalam Mewujudkan Kesejahteraan Berbasis Perspektif Lokalitas Dan Religius), Unand, Proceeding, 2017.
} 
reported or was not a concern of the local community. Such conditions, causing domestic violence cases are not resolved and are not touched by law and regulations ${ }^{44}$.

As evidence, for example in West Sumatra KDRT cases occur every more than 100 cases, but that can be touched by law enforcement is only not enough $50 \%$ of the cases, this can be seen from the data in the West Sumatra Regional Police Criminal Investigation Directorate, domestic violence cases touched by this institution can be seen from the table below:

Table Domestic Violence Cases Touched by Law Enforcement in the West Sumatra Regional Police Criminal Directorate General 2015-2017

\begin{tabular}{|c|c|c|c|c|c|c|c|c|}
\hline \multirow{2}{*}{ No } & \multirow{2}{*}{ Year } & \multicolumn{4}{|l|}{ Type } & \multicolumn{3}{|l|}{ Victim } \\
\hline & & Physical & Psychic & Sexual & Displaced & Husband & Wife & Children \\
\hline 1 & 2015 & 14 & 2 & 2 & 10 & - & 28 & 3 \\
\hline 2 & 2016 & 10 & 1 & 10 & 6 & 2 & 20 & 5 \\
\hline 3 & 2017 & 13 & 7 & 16 & 10 & 3 & 32 & 10 \\
\hline
\end{tabular}

Source : Silfia Hanani (2017)

Cases of domestic violence like that, become one of the causes of domestic violence cases can not be resolved quickly, ultimately directly or indirectly cases of violence are always increasing in number. Therefore, in examining the problems of domestic violence cases must be done with a variety of cultural approaches, not only can be done with formal legal approaches. Considering the problem of female violence, especially those that occur in the household, is still difficult to resolve through formal law, because it is caused by sociological and cultural ideological factors so that victims and the community are reluctant to report cases of violence experienced by women in the family to be formally resolved, the alternative is to strengthen the role of the most basic local institutions of a local community itself. One of the local institutions is the customary institution which has the power and loyalty to the indigenous people or the local community. In the Minangkabau community in West Sumatra, there are two local institutions that are most trusted by the community in solving problems in their lives, namely traditional institutions and religious institutions. There are two types of custom institutions, traditional institutions which are at the community level and at the level of government system that is recognized in the nagari government (local Minangkabau government). While religious institutions are a manifestation of the awareness of the Minangkabau people who have chosen Islam as their religion.

Institutions at the level of the clan of the customary institution that is resolving the problems that occur in his group without involving the wider customary parties. Settlement at this level is called settlement of internal clans. In the process of solving problems, it is also called solving at the outset. If there is no settlement at this initial level, then customary institutions that are at the level of the nagari government will finish it.

${ }^{44}$ Ibid. 


\section{Conclusion}

In Indonesia, violence against women in general is a problem that is experienced by many women, because the problem is like a pyramid that is small at its peak but large at the bottom, because to get exact numbers is very difficult. Especially if the violence occurs in the household, because the problem is still considered taboo and is still considered a family problem that is resolved by family. Before the entry into force of Law Number 23 of 2004, legal protection for women victims of husband violence is regulated in Article 356 paragraph 1, of the Criminal Code. Article 1365 Civil Code, Article 24 of Law No. 1 of 1974 concerning marriage, Article 1 of Law No. 7 of 1984 concerning Ratification of the Convention on the Elimination of All Forms of Discrimination Against Women / Women, Article 17 of Law No. 39 of 1999 concerning Human Rights (HAM). After the enactment of Law No. 23 of 2004 concerning the Elimination of Domestic Violence, perpetrators of domestic violence in households are regulated in Chapter II, Article 5, Article 6, Article 7, Article 8 and Article 9 of Law No. 23 of 2004. Criminal provisions are regulated in Article 44, Article 45, Article 46, Article 47, Article 48, Article 49 and Article 50. Domestic violence is a criminal act that needs to be resolved legally through the criminal justice system in the criminal justice mechanism as regulated in the Criminal Code as a Lex generalist and Law Number 23 of 2004 concerning the Elimination of Domestic Violence as a Lex Specialist in law enforcement that has been regulated by the Indonesian State.

Law Number 23 Year 2004 concerning the Elimination of Domestic Violence regulates that Protection is any effort aimed at providing security to victims carried out by families, advocates, social institutions, police, prosecutors, courts, or other parties both temporarily and based on a court decision. Protection that is expected by the victim is protection that can provide a sense of justice for the victim. Domestic violence where the majority of victims are women is, in principle, one of the phenomena of human rights violations so that this problem is a form of discrimination, especially against women and is a crime whose victims need protection from both government officials and the community. Legal protection for women victims of domestic violence still causes problems, especially in recognizing provisions in criminal law which require that a criminal act be prosecuted only because of a complaint.

\section{References}

Achie Sudiarti Luhulima Pemahaman Bentuk-bentuk Tindak Kekerasan Terhadap Perempuan dan Alternatif Pemecahannya, Alumni, Jakarta, 2000

Abnan Pancasilawati, Kekerasan Dalam Rumah Tangga Perspektif UU NO.23 Tahun 2004 tentang PKDRT dan Hukum Islam, Jurnal Equalita Vol 3 No 2 Juni 20013.

Bashim Kamla, Menggugat Patriaki, Pengantar Tentang Persoalan Terhadap Kaum Perempuan, Terjemahan Nursyahbani. Katjasungkana, What is Patriartichy, Yogyakarta: Benteng Kalyamamitra 1996,

Chaerudin dan Syarif Fadillah, Korban Kejahatan dalam Perspektif Viktimologi dan Hukum Pidana Islam, Grhadhika Press, Jakarta, 2003.

Dikdik M. Arief \& Elisatris Gultom, Urgensi Perlindungan Korban Kejahatan Antara Norma dan Realita, PT. Raja Grafindo Persada, Jakarta, 2007

Eva Achjani Zulfa, Reparasi dan Kompensasi Korban Dalam Restorative Justice, Lembaga Perlindungan Saksi dan Korban dan Departemen Kriminologi FISIP UI, Jakarta, 2011 
Eva Achjani Zulfa, Konsep Dasar Restorative Justice, Pelatihan Hukum Pidana dan Kriminologi, AsasAsas Hukum Pidana dan Kriminologi serta Perkembangannya Dewasa ini, Universitas Gajah Mada, Yogyakarta, 23-27 Februari 2014

Guse Prayudi, Berbagai Aspek Tindak Pidana Kekerasan Dalam Rumah Tangga, Yogyakarta: Merkid Press, 2008.

Hilman Hadikusuma, Metode Pembuatan Kertas Kerja Atau Skripsi Ilmu Hukum, Bandung:Mandar Maju,1995

Jan Remmelink, Hukum Pidana; Komentar atas Pasal-Pasal Terpenting dari Kitab Undang-Undang Hukum Pidana Belanda dan Padanannya dalam Kitab Undang-Undang Hukum Pidana Indonesia 1-3, Gramedia Pustaka Utama, Jakarta, 2003

Komnas Perempuan, Tergerusnya Ruang Aman Perempuan Dalam Pusaran Politik Populisme, Catatan Kekerasan Terhadap Perempuan Tahun 2017, Catatan Tahunan Tentang Kekerasan Terhadap Perempuan, 2018.

Luhulima, A.S, Pemahaman Bentuk-Bentuk Kekerasan terhadap Perempuan dan Alternatif Pemecahannya, Jakarta: PT.Alumni: 2000,

Lexy Y. Maleong, Metode Penelitian Kualitatif, Jakarta: Remadja Karya, Jakarta, 1999.

Mardjono Reksodiputro, Mengembangkan Pendekatan Terpadu Dalam Sistem Peradilan Pidana, Pra Seminar Hukum Nasional V, Jakarta, 21 Januari 1986.

Moerti Hadiati Soeroso Kekerasan Dalam Rumah Tangga Dalam Perspektif Yuridis-Viktimologis, Jakarta: Sinar Grafika, 2010.

Nursyahbani Katjasungkana, Seminar Aspek Hukum Kekerasan Terhadap Perempuan, BPHN, Jakarta, 15-16 Desember 1994.

Noeng Muhadjir, Metodologi Penelitian Kualitataif, Rake Sarasin, Yogyakarta, 1993

Peter Mahmud Marzuki., Penelitian Hukum, Kencana, Jakarta, Cet. VI, 2010

Ratna Batara Munti dalam Novianty Djafri, Jurnal INOVASI, Volume 5, Nomor 4, Desember 2008

Rianto Adi, Metodologi Penelitian Sosial dan Hukum, Granit, Jakarta, 2004

Silfia Hanani, Mengatasi Kekerasan Dalam Rumah Tangga Melalui Institusi Adat Minangkabau (Suatu Upaya Dalam Mewujudkan Kesejahteraan Berbasis Perspektif Lokalitas dan Religius),Conference Proceeding, Annual International Conference on Islamic studies (AICIS XII)

Soejono dan Abdurrahman, Metode Penelitian Suatu Pemikiran dan Penerapan, Rineka Cipta, Jakarta, 2005

Suryanti, Kekerasan Dalam Rumah Tangga (Analisis Fakta Sosial Berbasis Konseling Feminis Terhadap Ketimpangan Gender), Jurnal Musawa, Vol. 10 No.1 Juni 2018.

Soerojo Wignjondipoero, Pengantar dan Asas-asas Hukum Adat, PT. Toko Gunung Agung, Bandung, 1983

Silfia Hanani, Mengatasi Kekerasan Dalam Rumah Tangga Melalui Institusi Adat Minangkabau (Suatu Upaya Dalam Mewujudkan Kesejahteraan Berbasis Perspektif Lokalitas Dan Religius), Unand, Proceeding, 2017 


\section{Copyrights}

Copyright for this article is retained by the author(s), with first publication rights granted to the journal. This is an open-access article distributed under the terms and conditions of the Creative Commons Attribution license (http://creativecommons.org/licenses/by/4.0/). 